\title{
WEIRD RELIGIOUS BACKGROUNDS: LARRY NORMAN, JESUS ROCK, AND AN INTERVIEW WITH GREGORY ALAN THORNBURY
}

\author{
Rupert Loydell \\ Falmouth University
}

Keywords: Christianity, Larry Norman, Jesus Rock, CCM, Religion

'Christian rock is a genre that exists to edify and make money off evangelical Christians. [...] A Christian band, on the other hand is just a band that has more than one Christian in it.'

- John Jeremiah Sullivan (2012: 17-18)

Although The Bloomsbury Handbook of Religion and Popular Music (Stewart and Abraham 2017) contains chapters such as Michael J. Gilmour's 'The Bible and Popular Music' (67-76) and Ibrahim Abraham and Francis Stewarts' 'Punk and Hardcore' (241250), there remains little informed academic consideration of the Christian music genre, especially punk and post-punk. John J. Thompson's Raised by Wolves (2000) and Mark Joseph's The Rock \& Roll Rebellion (1999) offer insider histories, whilst Andrew Beaujon's Body Piercing Saved My Life (2006) is an hilarious, sceptical exploration of 'the phenomenon of Christian rock', focussed mostly on the early 2000s. Gilmour 's Call Me the Seeker: Listening to Religion in Popular Music (2005) is interested more in religious sources and themes; the nearest it gets to post-punk is Anna Kessler's consideration of Nick Cave (79-94) and J.R.C. Cousland's discussion of 'God, the Bad, and the Ugly' in the work of Nick Cave and Polly Harvey (129-157).

Better, is Jay R Howard \& John M. Streck's Apostle of Rock (1999), which takes a more sociological approach to what it calls 'The Splintered World of Contemporary Christian Music' and considers the tensions between ideas of ministry, entertainment, art and business for Christian musicians. It has an 'Interlude' (22-23) where it uses a description of a 1979 Larry Norman concert as a scene-setter before chapter 1 which discusses 'Origins and Oppositions: The Founding of CCM'.

The problem is that they are in the main American books discussing mostly American music, and have to negotiate and accept the existence of Contemporary Christian Music 
(CCM) as a monolithic business model, which it isn't (and never really has been) in the UK. If these books discuss punk \&/or post-punk, then it is usually in relation to the American hardcore, skatecore or grunge models from the 1990s onwards, not the 1970s UK or New York versions. Even bands such as U2 are presented as an aberration, a maverick band of Christians going it alone outside of Christian music, as heretics who smoke and drink too much, or as a group of guerilla musicians on some kind of spiritual hit and run mission.

The UK story of Christian/Jesus music seems to have been very different to the American one, and does not involve much punk \& post-punk either. It does not and never did have a similar version of huge Christian music labels/businesses to work with, resist, or write back to, and Christianity has long been regarded suspiciously as a mainstream, conservative and out-of-touch belief system, one controlled by, and of, the establishment. Discussions of religion, spirituality and the multicultural in relation to rock and pop music seem to have included most major and minor faiths but not Christianity. Perhaps now is the time to consider another subcultural history, another religious musical impulse that has shaped and informed much popular and alternative music over the last 50 years?

Christian music in 1960s UK was largely church-centred; mainly hymns and folk versions of the same, with perhaps an element of skiffle. The coffee shop was the model for any attempt to contact local youth culture (sans uppers, downers or jazz) and it was often done in the name of 'outreach' or 'ministry', an attempt to convert people and bring them into the church. It wasn't until the 1970s that Christians appeared to engage with the emerging rock culture.

The journalist and poet Steve Turner remembers that

Overall there was a feeling of Christians trying to catch up. When Woodstock happened they followed three years later with Explo in Dallas. When Jesus Christ Superstar and Godspell hit the stage they followed up with Lonesome Stone. (OST 1973). When I started writing about music professionally in 1971 there weren't many examples of people who were working in mainstream rock yet from a Christian perspective. Even though people would have argued by that stage that there didn't need to be a separation of secular and sacred it was just far easier for Christian musicians to remain in the religious market. (Turner 2018) 
I suggested to Turner that a lot of the activity in the UK seemed to derive from visiting US musicians. Liberation Suite, a heavy band with a brass section from Texas, toured, and Larry Norman and Randy Stonehill were based in London for a while, and also performing. I wondered how they compared to the homegrown music of Parchment (a folk trio from Liverpool), Nutshell (a melodic trio of singers headed up by Paul Field, later a writer of pop songs for Cliff Richard, Elkie Brooks and many others, and winner of an Ivor Novello Award) and Malcolm \& Alwyn (an acoustic duo who played autoharp and guitar).

Something existed then that doesn't happen now (in the UK) - major CCM artists doing national tours in prestigious venues. I suppose the worship music thing has taken over. But a band like Andrae Crouch and the Disciples would play major concerts. [...] I suppose UK music was scruffier, quieter and more modest. American music was brasher. I guess we still looked to America as being the innovator. (Turner 2018)

Singer, performance poet, and arts theologian Steve Scott concurred with this interpretation when I interviewed him (2012a) on the back of the release of Emotional Tourist: A Steve Scott Retrospective (2012b)

I finished art school [in London] in the mid-70s... I had been getting increasingly interested in multimedia and film, and at the same time I had been doing some songwriting. This came to the attention of Larry Norman, via Randy Stonehill who was living not too far from where I was at the time. One thing led to another and I ended up moving to the States in the late 70s to record material for the Solid Rock label.

By then of course, punk had happened in the UK, and although Christian rock bands and events such as the Greenbelt Arts Festival, continue to this day, I put it to Turner that the UK was ultimately unable to sustain a Christian musical subculture as the audience was simply too limited, whereas in the States it became big business. Some would say this was a good thing, and before too long the likes of After the Fire (new wave pop; 1979, 1980, 1982) and Writz (1979), who later became Famous Names and then The Technos (1985, 1988)/Techno Twins (1982)/Techno Orchestra (1982) (think arty postpunk pop), would abandon this subculture and fight for mainstream record deals, a subject 
Turner wrote about in his book Hungry for Heaven (1988). I asked if he thought that the likes of U2 and Bruce Cockburn, along with many others, talking about spirituality, though not traditional Christian beliefs, might be a direct result of previous artists fighting against pigeonholing, or has society simply moved on from being Christian to secular?

Because they were raised in Ireland rather than the UK, the guys in U2 weren't faced with the temptation of becoming part of a Christian subculture. In 1969 I had met David Rees and his whole idea - because Schaeffer (e.g. 1968, 1969, 1972) and Rookmaaker (1970) had influenced him - was to be a Christianinspired Rolling Stones or Bob Dylan. So a decade before U2 emerged I had been influenced by this attitude. (I introduced David to Writz and he managed them for a while and it's interesting that their lights guy Willie Williams is now U2's stage and lighting designer). I think in general some artists - like Cockburn - realised that all mainstream artists had beliefs and that it was ok to let your beliefs affect your music. You didn't have to join a subculture where you were only likely to play your songs to people who were in total agreement with you. The other thing that happened was that just when people were looking for 'a Christian Bob Dylan' Bob Dylan became 'the Christian Bob Dylan.' (Turner 2018)

I suggested that the availability of all music for free on the web, along with a renewed interest in how we might define ourselves, our beliefs, our sexuality, even our gender, seems to have provoked a renewed interest in subcultures. How does Turner feel about Jesus Rock being viewed in this way?

Jesus Rock never excited me. I didn't like the obviousness of it and the narrow focus of the lyrics. I also felt that they'd cut themselves off from the main conversation that was happening in music and what we used to call 'rock culture'. I was interested enough to want to meet these people though. I interviewed Country Faith for Beat Instrumental and in a similar way I arranged to meet Larry. I went along (I guess this was early 1972) with my notebook and thought I was going find an Arthur Blessitt with a guitar but instead I found someone who was passionate (and knowledgeable) about music and really understood his times and culture. I put the notebook away quite early on and that was the beginning of our friendship. We both learned a lot from each other. He was a great reader and besides music loved TV, movies, comic books, magazines, newspapers, comedy, 
theatre, photography, advertising, packaging and all forms of pop culture. He knew the value of everything from the clothes he wore, the way he walked on stage, his comments between songs, the album covers - he could explain exactly why he did each thing he did. He also thought Christianly about all he did. He had struggled as a teenager to make sense of the church and the Bible in the context of popular culture and he continued that struggle for the rest of his life. I miss his opinions. I would have liked what he created to have been tested much more in the general market and for him to take the advice of other people rather than trying to control absolutely everything. (Turner 2018)

It's this renewed interest in subcultures that partly facilitated the publication of Gregory Alan Thornbury's Why Should the Devil Have all the Good Music? (2018), but there's also a recognition that Larry Norman influenced a good number of musicians, despite leading a complicated and confusing life outside mainstream Christianity. Dave Di Sabatino's film Fallen Angel: The Outlaw Larry Norman (2009) relied upon hearsay, gossip and heavily edited interviews, as well as some great live footage, to suggest that Norman was inept, dishonest and the father of an illegitimate child in Australia. Norman's record label Solid Rock and artists agency Street Level both ended in acrimonious dissolution, and sometimes Norman's later records simply didn't stand up to critical scrutiny. Yet for a while he was one of the focal points of whatever Jesus Music was when it wasn't big business and hype. He spoke to people - literally and through his music - to encourage, challenge and make people think; an all too rare occurrence in Christian circles.

He was also unusual as a Christian musician in being overtly political and questioning. 'Reader's Digest', the closing track on Norman's Only Visiting this Planet LP (1972) takes digs at Alice Cooper, the Rolling Stones, David Bowie, John Lennon, the cost of the Apollo Moon landings, national radio stations and the lack of visionaries (or dreamers) left:

It's 1973, I wonder who we're gonna see

Who's in power now? Think I'll turn on my TV

The man on the news said China's gonna beat us

We shot all our dreamers, there's no one left to lead us

Norman then ducks responsibility for giving any answers: 'Don't ask me, I'm only visiting this planet.' This hope for another world (heaven) is echoed in the fade out of the song, where Norman's faint vocal continues, stating that 'This world is not my home, 
I'm just passing through...'

I previously reviewed Thornbury's book about Norman, Why Should the Devil Have All The Good Music? Larry Norman and the Perils of Christian Rock, for Punk \& Post-Punk (Loydell 2018), but thought I would ask the author for an interview about the writing of the book and the issues it raises (or sometimes avoids). Gregory Alan Thornbury is Vice President at the New York Academy of Art and Chancellor of The King's College. He is a sometimes reluctant interviewee and indicates the distrust of Larry Norman that still exists within religious culture, evidenced here by the ability to ignore some facets of Norman's life and to rely mostly on the 'Larry Norman Papers' which, as part of the estate, are controlled by Norman's brother Charles, rather than critical or contextual material.

Rupert Loydell: What is it that originally fascinated you about Larry Norman, that prompted you to write this book about him?

Gregory Alan Thornbury: I was working as a manager at a Christian FM station when I was in college in the early nineties. I pretty much hated everything I heard in Contemporary Christian Music. I was completely new to it. I was already playing music in college both solo and in bands, and I was already listening to great music: The Beatles, the Stones, Bob Dylan, Elvis Costello, The Clash, Squeeze, U2 - you name it. And nothing I heard was on that level. CCM sounded contrived, derivative, and well, just not very rock and roll. I rolled my eyes when I'd get the promotional material from the Christian record companies or CCM magazine when they would say things like 'if you like Billy Joel, you'll love David Meece!' For me, I didn't listen to the pastors or church leaders that tried to shame me for listening to secular rock and roll, so I didn't need Christian rock to fill a hole in my life. I was already reading the best philosophers and theologians, so I didn't look for faith-filled records to meet a need in my life spiritually or intellectually like other people.

Then one day, one of the DJs at the station said, 'Hey, I think there's one Christian artist you'd like.' And he took me to the room where they still kept all of the old vinyl records (we were playing all CDs by that point), and he pulled out Only Visiting This Planet (Norman 1972). I went into the sound booth and put it on. And from the moment the needle touched down (that version of the LP from MGM started with 'Why Don't You Look Into Jesus'), I was struck by how good the record was. It covered a range of topics 
which were verboten in CCM: sex, the American War machine, the institutional racism of the white Church, etc. There was a warning from a previous station manager not to play certain songs from Planet on the air. That got me intrigued. Plus, it was from a legitimate secular record label, and I thought, 'Wait, this guy is legit.' I later found out that he was the so-called 'father of Christian Rock.'

In the pre-internet age, it was hard to find out a lot of information about Larry, but I read somewhere that he was going to play at a Christian rock festival in Kentucky. I drove 750 miles to go see Larry with a friend of mine. When I saw him play, I was impressed. His songs were great. He held thousands of people spellbound. They were quiet when he spoke. It was almost as though there was an air of mystical importance to the performance that the other acts didn't have. Because we were from radio, we had the chance to go backstage at the festival, and I could observe the behaviour of the various artists. Larry hung out more than the other acts, and I remember seeing him praying a lot with people. That struck me. Other artists didn't act that way.

I listened to Larry's music over the years, and thought he was a terrific songwriter, but I kind of lost track of him until he died. And I was intrigued by the people who covered the story and wrote obituaries: The New York Times (Hever 2008), The Times of London (unknown 2008), Spin (Beaujon 2008), Paste Magazine (Whitman 2008), and the like. When many years later I was invited to take a look at Larry's archives and what he kept, I thought, 'Wow! There's so much more to this story.' A few months later, I had dinner with Peter Guralnick, the critically acclaimed biographer of Elvis (Last Train to Memphis (1994) and Careless Love (1999)), and I told him who Larry was, and what I had access to, with the permission of the estate, and he said, 'This is what I discovered at Graceland.' Shockingly, no one had gone through a lot of Elvis' personal things - trunks filled with stuff. He said, 'Larry Norman sounds a lot like Elvis in that respect. You ought to do it.'

RL: I wondered at what point in the writing of Why Should the Devil Have All the Good Music? the decision came to mainly rely on Larry's own archive rather than the critical and contextual material?

GAT: Well, there is quite a bit of critical and contextual material in the book, to be certain. People might be interested to know that the original manuscript was almost 50,000 words longer, but my contract called for 80-90,000 words. My agent, editors, and 
publisher unanimously said that while the extra material might be of interest to diehard fans, it wouldn't be compelling for the uninitiated average reader to introduce them to Larry Norman as an artist. 'Focus on the story,' everyone said in unison. We wanted the book to have a broader appeal, and the strategy seems to have worked splendidly - mainstream media outlets, journalists, and production companies are fascinated with the book because it focuses on the story and bigger themes that Christians still struggle with today. So I am grateful for that.

Also, as I read all of the stories, interviews, and mentions in books that were written on Larry over the years, I didn't find a lot of it that illuminating or interesting when I had the advantage of seeing what was actually happening behind the scenes through the archives. For example, nobody else had access to the nearly two hour audio tape of the meeting that led to the break up of Solid Rock Records and the resulting controversy related to the release of Daniel Amos's Horrendous Disc (1981). No one else had access to all of the letters from the lawyers and the heated correspondence and so forth. So I could do something with that which other commentators and opinion writers really couldn't do. I was working from primary sources and letters, which is always the best kind of research for a scholar.

Additionally, as I've talked to other biographers - like Warren Zanes who wrote the Tom Petty biography (2015) and who endorsed my bio on Larry - he and they have told me: 'Wow. The archives you have are just unprecedented. I didn't have anything close to this amount of personal correspondence and intimate information on . There's so much material. Lean into that.' So I decided to take their advice.

You know, I didn't set out to write a biography on Larry Norman. But several years ago, when I was invited to speak at a Jesus Movement exhibition focusing on the life of Larry Norman at Fuller Theological Seminary. Larry's brother Charles was there, along with Dizzy Reed from Guns'n'Roses. Larry's mother Margaret watched on Skype, from her home in Salem, Oregon. Everyone at Fuller who had worked on the Jesus Movement archive was pleased with the event and with my paper. Afterwards, Charles said 'You know, my brother kept everything.' I replied 'What do you mean by everything?' I was invited to come take a look, and I was blown away. Hundreds of boxes of multi-party correspondence, tapes of phone calls, handwritten diaries, journals, photos, studio record logs, films, passports, plane tickets, artifacts, and far more - all of the documentation behind his incredible life and copious detail on all of the controversies in 
his life. I felt transported back into the late 60 s and early 70s - it was all here. I wouldn't have to rely on memories that were forty or fifty years old to do this. It was a biographer's both dream and nightmare - but it was like being transported back to the era in a time machine.

RL: Would you concede that in many ways the book is Larry's own version of his story as much as yours? A kind of autobiography told in the third person through you? What made you trust Larry's own version of things rather than anyone else's?

GAT: The last time I checked, I am not a seminal rock pioneer who was instrumental in the Jesus Movement. LOL. So no, this isn't an autobiography. I am a scholar who has previously written on philosophy, history, theology, and pop culture. I just tried to tell the story as empathetically as I could. I didn't have any axes to grind.

For the record, I didn't rely on just 'Larry's own version of things' at all. You have to keep in mind that when I read correspondence or listened to audiotapes between Larry and various parties mentioned in the book, it was two-way correspondence. I got both sides of the story. But the one thing that's important about my access to this material is that I got to see the feelings and opinions of all of these people in black and white at the time of the events back in the sixties, seventies, and eighties. I wasn't relying on hazy memories of people getting on in years now, but documents from that era. That's something that Michael Nesmith (of The Monkees) talks about in his recent memoir, Infinite Tuesday (2017). He makes it clear that the accounts of the stories in his book are not 'things as they actually happened' but things as he remembered them forty and sometimes fifty years later. Big difference.

I did my dead level best to be judicious and fair to all parties. If Larry was wrong about something, I tried to say that it was his opinion, or that he was wrong. Still, Larry died before he had a chance to write a memoir, and there's been a lot of speculation and commentary about him since then. Everybody got to weigh in with their own contemporary viewpoints long after the events described. And what I found is that in a lot of cases, the record needed to be corrected because I had letters written in the hand of various interlocutors of Larry that cast light upon what really occurred.

With that being said, I did find that that often when I had doubts about something that Larry said happened, I prematurely judged his account of things as being wrong, and 
then I'd find evidence to the contrary that he was telling the truth. Let me give you just one of many examples. Larry said that he performed with People! on American Bandstand with Dick Clark in one of his notebooks. To the best of my ability, though, I could only find evidence that People! played on the show after Larry had left the band. So I assumed that Larry was sort of writing himself back into the picture. And then, lo and behold, video emerged on YouTube of Larry singing 'I Love You' with People! on Bandstand (People! 1968). This sort of thing happened time and time again. So often I'd confirm that Larry was a pretty reliable witness on the things that really mattered in the grand scheme of things.

RL: I was expecting more of a critical book than a biography. So I hope you don't mind if I ask you questions about Larry's work as much as the book itself. I was hoping you might unravel some of the speculation about all the albums that Larry continuously referred to yet which seem to have only been vague concepts rather than ever planned out or recorded.

GAT: Again, I found that that stuff was too 'insider baseball' and of interest to only a relatively small number of obsessed Larry Norman fans who are in their fifties and sixties by now. Believe me, it would have been kind of fun to have gone into that stuff, but my intention was to tell the story of a true American original that would be engrossing enough to capture the attention of a larger demographic of people. The readers of the book seem to be more interested in the stresses and pressures Larry encountered by trying to combine his faith with art in the midst of some pretty outrageous life circumstances, which are described in detail in the book.

Regarding the planned/discussed-but-never-released records (e.g. Voyages of the Vigilant), without knowing specifically what projects you're talking about, I can't comment other than to say this: sometimes Larry actually did plan out things pretty rigorously, and execute them, and sometimes he didn't. For instance, I thought that the rock musical Alison probably wasn't a fully realized project, and then I found all of the sheet music and a complete recording of the cast rehearsing the performance. I was blown away.

There are also albums released that he never teased or promised as well, so maybe it balances out. I think Stop This Flight (Norman 1985) has some very good songs on it, and for the time, I thought it was innovative to do a live album of new songs. But people 
seem to focus on the stuff that wasn't released rather than what was. But at the end of the day, I don't think that Larry was that much different from artists whose best creative output was in their early years.

What I know is that there is still unreleased material on master tapes that need to be transferred, but they need to be taken to the right facility, baked, handled with care, and so forth. That's expensive to do. We might be surprised at what still is left to hear.

That said, there were a bunch of projects that were teased but never realized. After Something New Under The Son (Norman 1981) and the events described in my book, Larry lost the drive and focus to deliver fully on some of the projects that seemed so tantalizing to fans.

RL: At times you mention Larry's own self-mythologising but you seem to never dwell on it. Larry was very charismatic, but isn't there something worrying about Larry's ability to spin a yarn, his way of re-telling a different version of what happened to suit the moment?

GAT: There was what he wrote on liner notes, newsletters, and said in interviews, to draw fans in and convince them that there was some hermeneutical key that unlocked hidden messages in songs and etc. Every artist that I find interesting does that. Bob Dylan does that in interviews, so does Kanye. Take a look at the Rolling Stone interview Dylan did on his transfiguration, for instance (Gilmore 2012). Did that really happen? It's a story that's definitely 'out there'. But the personal notes, diaries, biographical notes, tapes, and letters I read between all of the various parties gave me the opportunity to separate the truth from the PR and mythologizing, as much as was humanly possible for any third party could do. Without a specific incident you're referencing to respond to, though, I'll just leave it at that.

RL: And what about Larry's actual relationship to Christian rock? He seemed to want a foot in both the secular camp and a foot in the growing Christian festival and concert circuit, but antagonise both. Is that a position that makes any sense to you?

GAT: Well, yes, it does. Most artists have mixed feelings about their constituencies who buy their records. They've made their career with one constituency, but they also want to cultivate another. Taylor Swift is a prime example. She has a large following of adolescent girls, but she wanted to address more complicated artistic themes about the 
nature of living up to an image created for you by a publicity machine. She antagonized both critics and fans with her last record. This happens all the time. She wants to keep her young fans, but she's not going to record 1989 (2014) again. There's no going back. What to do?

But I do say at the very beginning of my book that Larry wanted to play it both ways. That's the tension implied in his life and career. That's why his story is so interesting. I live in New York City. I hear Christians wondering all of the time if they can stay Christian and still be in Broadway, in finance, or in the art world. That's why people in those spheres find Larry's story so interesting. He was caught in the tension, so the story is a parable.

Larry wanted his fellow Christian musicians to make art, and for it to be held to high standards as the secular record industry. And he was pretty hard on them when they wanted to take shortcuts or failed to live up to their potential. In a way, Larry was just trying to do what any decent evangelist or preacher tries to do: afflicted the comforted and comfort the afflicted.

I felt like the A.V. Club review of my book got the themes spot on (Vlastelica 2018). Read it here: https://t.co//m6GTlB1rX

RL: You set the book up as a series of chapters, most of the titled 'Jesus Versus (someone/something)' but isn't it really Larry Norman Versus the people and organisations concerned throughout? Jesus is quite a minor character in your book, so what informed that decision?

GAT: Well, I explained that in the introduction. I explained that Larry felt like he had an intimate and very close relationship with Jesus. And sometimes he couldn't distinguish between what was his point of view, and what the 'good Lord himself was thinking'. That's in the book. So the chapter titles are a literary device to highlight the way in which Christians often assume that 'God is on their side' - even when they're fighting with other Christians.

RL: You are very clear and lucid in your reporting of both Larry's divorce from Pamela and the way Solid Rock Records ended. Surprisingly so, as these have been rather obscured by rumours over the years. Do you think the end of Solid Rock was mismanagement (and I 
don't mean deliberate) or that there really weren't enough good musicians around who needed help? Or were willing to undertake a year's apprenticeship?

GAT: Thanks for saying that. There were mountains of material related to all of that and to summarize it all in a straightforward way was not easy.

My feeling is that the following was the case:

a.) The talent bench in Christian music was fairly short.

b.) The best artists (i.e. Randy Stonehill, Daniel Amos, Mark Heard, Steve Scott) wanted to get secular record contracts, but just weren't successful in doing so. And that's what they thought Larry could do for them.

c.) When Larry's expectations and standards were too high, or when Larry couldn't manage to get their records to market in a timely fashion, they went to other Christian record labels who had lower artistic requirements and could get records out more expeditiously. I totally get that. It was a compromise.

d.) Most of those artists signed with Solid Rock to get the advantage of having the Street Level booking agency thrown in, because as we all know, most artists make the real money on the road performing and selling merchandise. When Street Level split off from Solid Rock - the appeal of Solid Rock lessened.

RL: I'm also wondering about your perception of the Christian music industry at the time? I think in England it was slowly becoming clear that there wasn't a big enough audience to support the business model that was evolving in the USA. Also, that the cultures were very different at the time. Although some Christian arts festivals such as Greenbelt Festival continued over here, Christian labels were normally American subsidaries and not real market contenders.

GAT: I totally agree with you from what I could ascertain. Larry thought that he could recreate Solid Rock in the UK and that turned out to be a fool's errand. The market just wasn't big enough.

RL: In the late 1970s and early 1980 several UK Christian bands would work hard to establish themselves as secular bands out in 'real' rock world. This would include the Alwyn Wall Band, although they never quite managed to manouevre themselves artistically in the way After the Fire and Writz/Famous Names did. This would ultimately leave to the likes of U2 and perhaps Bruce Cockburn, as well as many other artistes, 
establishing themselves as musicians who happened to be Christians. Larry on the other hand seemed to lose his place a bit, although I know Frank Black of the Pixies and U2 revealed themselves as fans.

GAT: Add to Bono and Black Francis on the list of those revealing themselves as fans of Larry Norman the following artists: Damien Jurado, John Mellencamp, Nina Hagen, Doug Martsch (Built to Spill), Daniel Smith (Danielson), Dizzy Reed (Guns'n'Roses), Bill Mallonee (Vigilantes of Love), authors such as William Paul Young (The Shack), movie producers and directors such as Erik Lokkesmoe and Aaron Wiederspahn, actors such Martin Sheen and his son Emilio Estevez, Sarah Masen, Sareena Maneesh, Steve Albini (Shellac), Isaac Brock (Modest Mouse), The Welcome Wagon, The Kernal, Duquette Johnston, Roman Candle, and Bob Dylan just to name a few.

Not a bad list. I'd hardly call that 'losing his place'. I think any artist would be glad for these sorts of artists to be a part of his/her legacy.

RL: One thing your book does skip over is Larry's later years as a cottage industry and small business, issuing CDRs and live concert tapes, engaging with fans online and by letter, occasionally venturing out for small series of live tours, and still telling stories about missing albums which seem to never have existed and future plans which were never likely to happen. I wondered why so much time gets compressed into such a small section of your book?

GAT: I think I've already addressed this subject above. The book was not designed only for Larry Norman enthusiasts, and the editors at Random House thought information like this didn't contribute much to the story, which needed to be quick paced and cinematic for the book to gain a wider audience. Based upon the fact that the book has gotten such a wide reception, I think that was the right decision.

I am certainly all for continuing those conversations, but that sort of information if covered in detail would have bogged down the pacing of the book. Larry's last fifteen years didn't need that sort of scrupulous detail, because quite frankly, he was very ill and they weren't that interesting from a critical or story development point of view.

RL: Despite a generally-agreed artistic decline since his earlier albums such as Upon This Rock (1970), Only Visiting This Planet (1972) and So Long Ago the Garden (1973), here 
we are talking about Larry Norman in 2018 and your new book. What's the enduring appeal? Who is this book for, a decade after he died? There aren't that many fans left, so I am assuming you envisage a different audience? Why and what do they need to know about Larry?

GAT: Well, the United States Library of Congress thought Larry Norman had enduring appeal when it added Only Visiting This Planet into the National Recording Registry as a culturally, historically, and aesthetically compelling original work of American of Art in 2014 (cf, Koch 2014). I've also been surprised at the fact that several significant film production companies have already approached me about the availability of the film rights to the biography. I didn't even seek them out. They've come to me. They say that this is an engrossing and compelling story.

The people interested in this book have run the gamut from both Christian and nonChristian sources: NPR, The A.V. Club, The Washington Post, Christianity Today, The Christian Century, major national Christian websites, various regional public radio outlets, both secular and faith based podcasts, and quite a few others. I was intrigued by the reaction from a show on Wisconsin Public Radio called 'Beta' in which the host didn't know anything about Larry Norman, but found the book and the themes in it somehow engrossing and compelling. Several people working there started reading the book, and they are dedicating a whole show to it.

I've also heard from people all around the world whose lives were touched in some way by Larry. They've just come out of the woodwork. They're reliving a part of their lives. We forget that the Jesus Movement was a huge phenomenon from a cultural point of view. Some of these people are still Christians and others are not. But all of them had a connection somehow to Larry Norman. Are they still fans? That doesn't really matter, I suppose. But they remember the Jesus Movement, that heady time, those Larry Norman concerts, and that weird religious world still ongoing through which some of them emerged from as survivors.

This book is about weird religious backgrounds - mine, yours, and everybody else's.

But I've been more interested in the young artists who are reading this book as an insight as to how to do what Larry did at times both successfully and at other times unsuccessfully: navigating the tensions between faith and art. This book is for the people 
torn between those two worlds. Super fans have and will continue to engage in online forums about what albums were released and which weren't. But that's not really that interesting except to a few Larry Norman nerds. His incredible sojourn in this world, his personal battles with believers, his struggle to create art in the midst of difficult life circumstances is what people are drawn to. That's a good thing, in my opinion.

Why Larry Norman and why now? Well, it's been ten years since he passed, and his story was just so colourful. It was compelling, inspirational, and really twisty. I couldn't think of anyone close to being like him in recent Christian history. He was an American original. Larry blazed a trail by walking a tight rope tied high between two worlds: a secular rock music business that had little interest in Jesus or religion and a Western church filled with pastors and leaders who thought that Rock and Roll really was Satanic. Young people today don't remember a time when their parents and church officials told them their souls were in mortal peril if they didn't bring their Beatles and Led Zeppelin albums to bonfires to be burned. Larry came crashing into all of that and stood athwart two opposing worlds and said 'You're all wrong. Rock and Roll came from the black church and it's time to confront racism and steal it back.'

Also, Larry Norman was really good as an artist. His records hold up today as works of art. Isaac Brock (the lead singer/songwriter from Modest Mouse) was blown over when he heard his first Larry Norman record. I heard him say: 'I'm not into the religious part, but man, Larry Norman was a **expletive** hot songwriter.' Larry had the talent to be recognized by the entertainment industry and the Hollywood set. People don't just get offered multiple serial contracts from major record labels like Capitol, Elektra, MGM/Verve, Polydor, ABC, etc. He was working with Herb Hendler at Capitol - one of the great talent developers and producers of the twentieth century. He played on bills with the biggest acts of his time: The Who, Janis Joplin, Jimi Hendrix, and the doors. He jammed all night at the Ark Club in Sausilito, California with Skip Spence from Moby Grape, Neil Young and Stephen Stills from Buffalo Springfield. What other Christians were even close to being on and inside this scene during the nation's convulsive cultural and secular revolution? Larry Norman stood alone in that respect.

Larry inspired other artists and his fans. His life was so weird and wonderful, it caused tremendous jealousy, intrigue, and curiosity from anyone who met him. In sum, I felt like all of the messy beauty of Larry's life is needed in the world right now - especially among Christians - because there's a lot of self-righteousness in the world and 
Norman's life just forces a certain amount of introspection about what we're really doing with our own lives individually. This biography is psychological in nature. I hope it forces people not just to scrutinize Larry's life, but ideally their own. It's designed to disturb the complacency of the Christian community, so it seems to be working in that respect.

Add to this the various people today that look back upon Larry's albums as a light shining through their childhoods - some of whom were more isolated in a Christian subculture that would not let you listen to secular rock music. I've heard from countless people about how the quality, gravitas, and songwriting excellence of Larry Norman was an absolute Godsend.

He had incredible range. Listen to 'Moses in the Wilderness' (1970), 'Pardon Me' (1972), 'Be Careful What You Sign' (1973), 'Shot Down' (1981) and 'The Son Began to Reign' (1981) back to back. There are classical, rhythm and blues, and Broadway references in his songwriting. He's a throwback to an older era in which the sonic palette was deeper, more historical, and culturally wider in American music. And then there are the lyrics: 'I Don't Believe in Miracles' (1970), 'The Great American Novel' (1972), and 'Baroquen Spirits' (1973), compete with anything from Dylan or Leonard Cohen in my opinion.

\section{RL: Thank you for your time.}

\section{GAT: Thanks!}

\section{NOTE}

I am aware how 'WASP' this interview article seems, apart from Steve Turner's mention of Andrea Crouch. Clearly, there is another story to be told of soul and gospel and CCM music, a story that Larry Norman and most of the musicians cited here were not really part of (although Norman grew up in a black neighbourhood, and knew and sometimes performed in the same concerts as Crouch). Norman recalls [1980] that Crouch told him: 'Man, I always hear rumours about you. For a white boy, you sure get in a lot of trouble.' John Jeremiah Sullivan highlights the race divide within his article about the huge free (American) Christian music festival Creation: 'When I asked one woman, later, how many [of the audience] she reckoned were white, she said, "Roughly one hundred per cent."' (2012: 10) 


\section{ACKNOWLEDGEMENTS}

The author would like to thank Martin Caseley, Dougie Adams and Steve

Scott for information and ideas about Larry Norman and his music; Steve Turner and Gregory Alan Thornbury for answering my interview questions; and Russ Bentley and Mike Dines for help with editing and rewriting this piece. And Paul Platt, wherever he is.

\section{REFERENCES}

After the Fire (1979). Laser Love. London: CBS.

After the Fire (1980). 80-f. London: Epic.

After the Fire (1982). Batteries Not Included. London: CBS.

Beaujon, Andrew (2006). Body Piercing Saved My Life: Inside the Phenomenon of Christian Rock. Cambridge, MA: Da Capo.

Beaujon, Andrew (2008). 'God Only Knows. The Legacy of Larry Norman, who inspired Dylan, U2, and the Pixies', Spin, May 2008, p120.

https://books.google.co.uk/books?id=kic4tNzhZF8C\&pg=PA120\&lpg=PA120\&dq=la rry+norman+obituary+spin+magazine $\&$ source=bl\&ots=XAP6V-

02hP\&sig=E5FlEtjW_xpTWAsK-k-

JuQgaXVk\&hl=en\&sa=X\&ved=2ahUKEwi4opP_hNHaAhVKY1AKHVPPAPwQ6AEwBXo ECAAQcg\#v=onepage $\& \mathrm{q}=$ larry $\% 20$ norman $\% 20$ obituary\%20spin $\% 20$ magazine $\& \mathrm{f}=\mathrm{fa}$ lse (accessed 23 April 2018).

Daniel Amos (1981). Horrendous Disc. Los Angeles: Solid Rock.

Di Sabatino, Dave (dir.) (2009). Fallen Angel: The Outlaw Larry Norman. Nampa, ID: Jester Media.

Gilmore, Michael J., ed. (2005). Call Me the Seeker: Listening to Religion in Popular Music. New York: Continuum.

Gilmore, Mikal (2012). 'Bob Dylan Unleashed', Rolling Stone, Sept 272012. https://www.rollingstone.com/music/news/bob-dylan-unleashed-a-wild-ride-onhis-new-lp-and-striking-back-at-critics-20120927 (accessed 23 April 2018)

Guralnick, Peter (1994). Last Train to Memphis: The Rise of Elvis Presley. London: Little, Brown \& Company.

Guralnick, Peter (1999). Careless Love: The Unmaking of Elvis Presley. London: Little, Brown \& Company. 
Hever, Dennis (2008). 'Larry Norman, Singer of Christian Rock Music, Dies at 6o', New York Times March 42008.

https://www.nytimes.com/2008/03/04/arts/music/04norman.html (accessed 23 April 2018).

Howard, Jay R. \& Streck, John M. Apostles of Rock: The Splintered World of Contemporary Christian Music. Lexington: The University Press of Kentucky.

Joseph, Mark (1999). The Rock \& Roll Rebellion: why people of faith abandoned rock music - and why they're coming back. Nashville: Broadman \& Holman.

Koch, Jeff (2014). 'Christian rocker Larry Norman recognized as American musical treasure', World 11 April 2014.

https://world.wng.org/2014/04/christian_rocker_larry_norman_recognized_as_an_a merican_musical_treasure? (accessed 23 April 2018).

Liberation Suite (1975), Liberation Suite. Hemel Hempstead: Myrrh.

Lonesome Stone, original London Cast (1973). Lonesome Stone. London: Reflection.

Loydell, Rupert (2018). Book review: 'Why should the Devil have all the Good Music?

Larry Norman and the Perils of Christian Rock, Gregory Alan Thornbury (2018)', Punk \& Post-Punk 7.2, pp.277-280.

Malcolm \& Alwyn (1972), Fool's Wisdom. London: Pye.

Malcolm \& Alwyn (1974), WildWall. New Malden: Key.

Nesmith, Michael (2017). Infinite Tuesday: An Autobiographical Riff. New York: Crown/Penguin Random House.

Norman, Larry (1970). Upon This Rock. Los Angeles: Capitol.

Norman, Larry (1972). Only Visiting This Planet. Los Angeles: Verve/MGM.

Norman, Larry (1973). So Long Ago The Garden. Los Angeles: MGM.

Norman, Larry (1980). 'Don Gillespie interviews Larry Norman for New Music Magazine', New Music Magazine, January 1980.

http://www.larrynorman.uk.com/word24.htm (accessed 17 July 2018)

Norman, Larry (1981). Something New Under the Son. Los Angeles: Solid Rock.

Norman, Larry (1985). Stop This Flight!. San Jose: Phydeaux.

Nutshell (1976). In Your Eyes. Hemel Hempstead: Myrrh.

Nutshell (1977). Flyaway. Hemel Hempstead: Myrrh.

Parchment (1972). Light Up the Fire. London: Pye.

Parchment (1973). Hollywood Sunset. London: Pye.

Parchment (1975). Shamblejam. Hemel Hempstead: Myrrh.

Partridge, Christopher and Moberg, Marcus, eds. (2017). The Bloomsbury Handbook of Religion and Popular Music. London: Bloomsbury. 
People! (1968). 'People! On American Bandstand 1968' performing 'I Love You'.

https://www.youtube.com/watch?v=p80BEHcTnxk (accessed 23 April 2018).

Rookmaaker, Hans (1970). Modern Art and the Death of a Culture. Chicago: Intervarsity. Scott, Steve (2012a). Interview with the author.

Scott, Steve (2012b). Emotional Tourist. A Steve Scott Retrospective, : Arena Rock

Schaeffer, Francis (1968). Escape From Reason. London: InterVarsity

Schaeffer, Francis (1969). Death in the City. Chicago: InterVarsity

Schaeffer, Francis (1972). Art and the Bible. Downers Grove: InterVarsity.

Sullivan, John Jeremiah (2012). 'Upon This Rock' in Pulphead 3-41. London: Vintage.

Swift, Taylor (2014). 1989. Nashville: Big Machine.

Technos, The (1985). Foreign Land. London: PRT.

Technos, The (1988). Songs for a Nervous World. USA: Refuge.

Techno Orchestra (1982). Casualtease. London: Street Tunes.

Techno Twins, The (1982). Technostalgia. London: PRT.

Thompson, John J. (2000). Raised By Wolves: the story of Christian Rock \& Roll. Toronto: ECW.

Thornbury, Gregory Alan (2018). Why Should the Devil Have All The Good Music? New York: Convergent.

Turner, Steve (1988). Hungry for Heaven: Rock and Roll and the Search for Redemption. London: Virgin.

Turner, Steve (2018). Interview with the author.

Unknown author (2008). 'Larry Norman', Times Online 8 Mar 2008.

http://www.larrynorman.com/uploads/7/0/9/5/7095730/london-the_times.pdf (accessed 23 April 2018).

Vlastelica, Ryan (2018). 'The founder of christian rock would've hated what it's become', A.V. Club, 19 March 2018. https://www.avclub.com/the-founder-of-christian-rockmusic-wouldve-hated-what-1823533655 (accessed 23 April 2018).

Whitman, Andy (2008). 'Larry Norman', Paste Magazine 25 February 2008.

https://www.pastemagazine.com/blogs/whitman/2008/02/larry-norman.html (accessed 23 April 2018).

Writz (1979). Writz. London: Electric.

Zanes, Warren (2015). Petty: The Biography. New York: MacMillan.

\section{CONTRIBUTOR DETAILS}


Rupert Loydell is Senior Lecturer in the School of Writing and Journalism at Falmouth University, the editor of Stride magazine, a contributing editor to international times, and a widely published poet. He has written for academic journals such as Punk \& PostPunk, New Writing, Axon, Text, Journal of Writing in Creative Practice, Short Fiction in Theory \& Practice, Revenant, The Journal of Visual Art Practice, and contributed a cowritten chapter to Brian Eno. Oblique Music (Bloomsbury, 2016) and a forthcoming book on Twin Peaks: The Return.

Contact: School of Writing and Journalism, Falmouth University, Falmouth Campus, Woodlane, Falmouth TR11 4RHUK.SEPE!

E-mail: rupert.loydell@falmouth.ac.uk

(6093 words, excluding refs) 